\title{
POWIERZANIE ZADAŃ Z ZAKRESU GOSPODARKI KOMUNALNEJ A SWOBODA ZAWIERANIA UMÓW
}

\section{WPROWADZENIE}

Jak podkreśla się w literaturze: „decentralizacja władzy publicznej [...] nie ma w sensie normatywnym znaczenia waskkiego, jedynie »administracyjnego«, lecz stanowi odwzorowanie doktryny pomocniczości w kontekście politycznym i państwowym, a więc pozycji i uprawnień wspólnot obywatelskich do zarządzania swoimi sprawami, wiąże się zatem z szerokim zakresem przekazania odpowiedzialności za sprawy publiczne o znaczeniu lokalnym i regionalnym do gestii samorządu terytorialnego"'. Wynika z tego, że istoty samorządu nie należy upatrywać w klasycznej decentralizacji funkcji władczych państwa, a w decentralizacji ustroju i zadań (art. 15 ust. 1 Konstytucji $\left.\mathrm{RP}^{2}\right)^{3}$. Samorzą terytorialny, w myśl art. 163 Konstytucji RP, wykonuje zadania publiczne niezastrzeżone przez Konstytucję lub ustawy dla organów innych władz publicznych. Artykuł 166 ust. 1 Konstytucji RP stanowi, że zadania publiczne służące zaspokajaniu potrzeb wspólnoty samorządowej sa wykonywane przez jednostkę samorządu terytorialnego jako zadania własne. W literaturze słusznie przyjmuje się, że „w zakresie zadań samorządu terytorialnego mieści się gospodarka komunalna rozumiana szeroko jako zadania własne o charakterze gospodarczym realizowane w znacznej mierze w sferze dominium, także z wykorzystaniem instrumentów władczych"4. Niewątpliwie zakres gospodarki komunalnej jest determinowany statusem, jaki wyznacza jednostkom samorządu terytorialnego Konstytucja $\mathrm{RP}^{5}$. To

${ }^{1}$ Za: M. Kulesza, Gospodarka komunalna - podstawy i mechanizmy prawne, „Samorząd Terytorialny" 22, 2012, nr 7-8, s. 14.

${ }^{2}$ Dz. U. 1997, Nr 78, poz. 483 ze sprost.

${ }^{3}$ M. Kulesza, op. cit., s. 12-13. Zob. też: R. Stober, Prawo administracyjne gospodarcze, Warszawa 2013, s. 105; T. Rabska, Zasada gospodarki rynkowej a samodzielność jednostek samorzadu terytorialnego, w: A. Gomułowicz, J. Małecki (red.), Ex iniuria non oritur ius. Księga ku czci Profesora Wojciecha Eqczkowskiego, Poznań 2003, s. 94 i n.

${ }^{4}$ M. Kulesza, op. cit., s. 8.

${ }_{5}^{5}$ M. Szydło, Konstytucyjnoprawna dopuszczalność działalności gospodarczej jednostek samorzqdu terytorialnego a przepisy prawa samorzqdowego, „Kontrola Państwowa” 2010, nr specjalny (3), s. 22 . 
ustawa zasadnicza przesądza, że zadania publiczne służące zaspokajaniu potrzeb wspólnoty samorządowej są wykonywane przez jednostkę samorządu terytorialnego jako zadania własne (art. 166 ust. 1 Konstytucji RP).

W art. 1 ust. 1 ustawy z 20 grudnia 1996 r. o gospodarce komunalnej ${ }^{6}$ ustawodawca stanowi, że gospodarka komunalna polega na wykonywaniu przez jednostki samorządu terytorialnego zadań własnych w celu zaspokojenia zbiorowych potrzeb wspólnoty. $\mathrm{Z}$ art. 1 ust. 2 wynika, że gospodarka komunalna obejmuje „w szczególności zadania o charakterze użyteczności publicznej, których celem jest bieżące i nieprzerwane zaspokajanie zbiorowych potrzeb ludności w drodze świadczenia usług powszechnie dostępnych". Zadania o charakterze użyteczności publicznej stanowią tylko element zadań własnych jednostek samorzadu terytorialnego i nie wyczerpują całego obszaru gospodarki komunalnej. Nie jest celem opracowania przytaczanie w tym miejscu poglądów nauki na temat rozumienia gospodarki komunalnej, jej zakresu, czy dokonywanie analizy pojęcia zadań własnych oraz zadań użyteczności publicznej7 ${ }^{7}$ Prowadzone rozważania dotyczyć będą regulacji zawartej w art. 3 ust. 1 u.g.k. zgodnie z która, ,jednostki samorządu terytorialnego w drodze umowy mogą powierzać wykonywanie zadań z zakresu gospodarki komunalnej osobom fizycznym, osobom prawnym lub jednostkom organizacyjnym nieposiadającym osobowości prawnej, z uwzględnieniem przepisów ustawy z 27 sierpnia 2009 r. o finansach publicznych $^{8}$, w trybie przepisów ustawy z 19 grudnia 2008 r. o partnerstwie publiczno-prywatnym ${ }^{9}$, przepisów ustawy z 9 stycznia 2009 r. o koncesji na roboty budowlane lub usługi ${ }^{10}$, przepisów ustawy z 29 stycznia 2004 r. - Prawo zamówień publicznych ${ }^{11}$, przepisów ustawy z 24 kwietnia 2003 r. o działalności pożytku publicznego i o wolontariacie ${ }^{12}$ i ustawy z 16 grudnia 2010 r. o publicznym transporcie zbiorowym ${ }^{13}$ albo na zasadach ogólnych".

${ }^{6}$ T.jedn.: Dz. U. 2011, Nr 45, poz. 236 (dalej jako: u.g.k.).

${ }^{7}$ Zob. w szczególności: C. Banasiński, M. Kulesza, D. Szafrański, Ustawa o gospodarce komunalnej. Komentarz i przepisy towarzyszace, Warszawa 1997; S. Dudzik, Działalność gospodarcza samorzadu terytorialnego. Problematyka prawna, Kraków 1998; J. Gola, Wykonywanie zadań o charakterze użyteczności publicznej przez jednostki samorzqdu terytorialnego a działalność gospodarcza, „Przegląd Prawa i Administracji” 98, 2014, s. 25 i n.; K. Horubski, Pojęcie zadań użyteczności publicznej $w$ ustawie o gospodarce komunalnej - granice znaczeniowe, „Przegląd Prawa i Administracji” 98, 2014, s. 35 i n.; C. Kosikowski, Komentarz do ustawy o gospodarce komunalnej oraz wzory aktów gminy dotyczace przekształceń przedsiębiorstw komunalnych, Łódź-Zielona Góra 1997; T. Rabska, Nowe zagadnienia prawne „gospodarki komunalnej”, w: Ksiega pamiatkowa Profesora Eugeniusza Ochendowskiego, Toruń 1999, s. 263-280; eadem, Zakaz działalności gospodarczej, „Wspólnota” 1993, nr 21.

8 T.jedn.: Dz. U. 2013, poz. 885 ze zm. (dalej jako: u.f.p.).

9 T.jedn.: Dz. U. 2009, Nr 19, poz. 100 ze zm. (dalej jako: u.p.p.p.).

${ }^{10}$ T.jedn.: Dz. U. 2015, poz. 113 (dalej jako: „ustawa o koncesji na roboty budowlane” lub „u.k.r.b.u.”).

11 T.jedn.: Dz. U. 2013, poz. 907 ze zm. (dalej jako: p.z.p.).

${ }^{12}$ T.jedn.: Dz. U. 2014, poz. 1118 ze zm. (dalej jako: „ustawa o działalności pożytku publicznego" lub „u.d.p.p.w.”).

${ }^{13}$ Ustawa z 16 grudnia 2010 r. o publicznym transporcie zbiorowym, t.jedn.: Dz. U. 2011, Nr 5, poz. 13 ze zm. (dalej jako: „ustawa o publicznym transporcie” lub „u.p.t.z.”). 
Zaznaczyć też należy, że opracowanie nie obejmuje wszystkich zagadnień dotyczących powierzania zadań z zakresu gospodarki komunalnej, ale ogranicza się wyłącznie do tych, które dotyczą sposobu powierzania zadań w drodze umowy i przysługującej w tym zakresie jednostkom samorządu terytorialnego swobody kontraktowania, w tym swobody w podjęciu decyzji o zawarciu określonej umowy. Nie bez znaczenia w tym kontekście pozostaje pogląd, że proces rozwoju ustawodawstwa w zakresie gospodarki komunalnej nie został zakończony ${ }^{14}$ i dotyczy różnych kwestii, w tym także zakresu „swobody” jednostek samorządu w doborze środków (form) zapewniajacych coraz efektywniejszą realizację nieznanych dotychczas i często złożonych zadań publicznych. Z jednej strony w nauce stwierdza się, że ciężar ustalenia form prawnych, za pomoca których administracja wykonuje swoje funkcje, należy do kompetencji zastrzeżonej dla regulacji ustawowej ${ }^{15}$, z drugiej - postuluje się respektowanie swobody organizatorskiej gminy w sferze gospodarki gminy i podkreśla, że zbyt szczegółowa regulacja prawna może godzić w samodzielność jednostki samorządu terytorialnego ${ }^{16}$. Według utrwalonego w doktrynie ${ }^{17}$ poglądu powierzenie zadań na podstawie art. 3 ust. 1 u.g.k. ogranicza się do zastosowania formy umowy cywilnoprawnej. Więcej, w ocenie sądów administracyjnych stosunek powierzenia zadania jest stosunkiem cywilnoprawnym, albowiem powstaje na podstawie umowy, a nie na skutek przekazania przez gminę swoich kompetencji owemu podmiotowi ${ }^{18}$.

W kontekście rozwiązań prawnych zawartych w ustawach o: partnerstwie publiczno-prywatnym, koncesji na roboty budowlane, publicznym transporcie, które przewidują nieznany dotychczas sposób realizacji zadań publicznych warto to stanowisko poddać ocenie. Określenie bowiem przez ustawodawcę specyficznych warunków zawierania umów, ich istotnych elementów, kształtujących nierówne prawa i obowiązki stron stwarza uzasadnione przekonanie, że w sferze gospodarki komunalnej dochodzi do zmian w zakresie form działania administracji. W tym miejscu można postawić pytanie, czy nowe formy działania zapewniaja jednostkom samorządu terytorialnego taką samą swobodę, jaka wiąże się ze stosowaniem form cywilnoprawnych. Innym problemem jest tryb kontroli nowych typów umów, na podstawie których dochodzi do powierzenia zadania publicznego. Jak słusznie zauważa się w doktrynie, struktura prawnej kontroli współdziałania podmiotów publicznych i prywatnych

${ }^{14}$ L. Kieres, Prawo gospodarki komunalnej - zakres przedmiotowy i sfery interesu publicznego, w: J. Supernat (red.), Między tradycja a przeszłościa w nauce prawa administracyjnego. Księga jubileuszowa dedykowana Prof. Janowi Bociowi, Wrocław 2009, s. 279.

${ }^{15} \mathrm{~K}$. Strzyczkowski, Uwagi o zadaniach nauki o formach prawnych administracji gospodarczej, w: B. Popowska, K. Kokocińska (red.), Instrumenty i formy prawne działania administracji gospodarczej, Poznań 2009, s. 50.

${ }^{16}$ M. Kulesza, op. cit., s. 9; K. Kokocińska, Samodzielność jednostek samorządu terytorialnego w organizowaniu ustug publicznych, „Przegląd Prawa i Administracji” 98, 2014, s. 80 i n.

17 Zob. w szczególności: B. Dolnicki, Samorząd terytorialny, Warszawa 2009, s. 382; B. Jaworska-Dębska, Umowy we współczesnej administracji, w: J. Boć, L. Ludmiła Dziewięcka-Bokun (red.), Umowy w administracji, Wrocław 2008, s. 19; M. Szydło, Ustawa o gospodarce komunalnej. Komentarz, Warszawa 2008, s. 184.

18 Wyrok NSA z 24 września 2014 r., II OSK 1314/14, www. orzeczenia.nsa.gov.pl. 
nabiera obecnie szczególnego znaczenia i podlega istotnym zmianom ${ }^{19}$. Zmiany te zaobserwować można także w tej kwestii. Ograniczone ramy opracowania raczej nakazują zasygnalizować narastające problemy, aniżeli rozstrzygać je w sposób wyczerpujący.

\section{SWOBODA KONTRAKTOWA A POWIERZANIE ZADAŃ Z ZAKRESU GOSPODARKI KOMUNALNEJ}

Problematyka swobody umów w prawie cywilnym doczekała się licznych opracowań ${ }^{20}$. W tym miejscu warto jedynie wskazać, że oznacza ona możliwość ułożenie stosunku prawnego według swego uznania, aby jego treść lub cel nie sprzeciwiały się właściwości (naturze) tego stosunku, ustawie ani zasadom współżycia społecznego (art. $353^{1}$ k.c.). Wyrazem autonomii stron, co akcentuje Sąd Najwyższy w uchwale z 28 czerwca 1995 r., jest swoboda co do tego, czy chcą zawiązać między sobą stosunek obligacyjny (a więc czy zobowiązanie umowne w ogóle powstanie), swoboda wyboru kontrahenta, możność ukształtowania według swego uznania takiego stosunku zobowiązaniowego, jaki odpowiada ich interesom ${ }^{21}$. W literaturze podkreśla się, że najszerszy zakres autonomii stron wyraża się w przyznaniu podmiotom ogólnej kompetencji do swobodnego kształtowania umów obligacyjnych w zakresie ich zawarcia, treści i celu umów, czasu trwania, doboru kontrahenta itp. Natomiast watpliwości budzi pogląd, że zasada swobody umów określa także swobodę w zakresie formy umowy ${ }^{22}$. Przeważający jest jednak pogląd, że swoboda umów wiąże się z czterema zasadniczymi cechami: 1) swoboda zawarcia lub niezawarcia umowy, 2) możliwość swobodnego wyboru kontrahenta, 3) możliwość kształtowania treści umowy co do zasady w sposób dowolny, 4) możliwość wyboru co do zasady formy umowy ${ }^{23}$.

Możliwość swobodnego układania stosunku prawnego nie oznacza jednak dowolności i doznaje ograniczeń, które wynikać mogą m.in. z reżimów prawnych o charakterze innym niż zobowiązaniowy. Swobodę umów ograniczają z pewnościa regulacje prawa publicznego ${ }^{24}$, w tym przepisy ustawy o gospodarce komunalnej.

${ }^{19}$ K. Kiczka, Wybrane zagadnienia kontroli wspótdziałania podmiotów publicznych i prywatnych w sferze gospodarki komunalnej, „Przegląd Prawa i Administracji” 98, 2014, s. 48 i n.

20 Szerzej: Z Radwański, Umowy w: System prawa cywilnego, t. 3, cz. 1: Prawo zobowiazań. Część ogólna, red. Z Radwański, Wrocław-Warszawa-Kraków-Gdańsk-Łódź 1981, s. 360; R. Trzaskowski, Granice swobody kształtowania treści i celu umów obligacyjnych, Kraków 2005, s. 33-34; P. Machnikowski, Swoboda umów wedtug art. $353^{1}$ KC. Konstrukcja prawna, Warszawa 2005, s. 143; A. Olejniczak, Komentarz do art. 353(1) Kodeksu cywilnego, w: A. Kidyba (red.), Kodeks cywilny. Komentarz, Warszawa 2005, s. 30.

21 III CZP 166/94, OSNC 1995, nr 10, poz. 135.

22 A. Olejniczak, Komentarz do art. 353(1) Kodeksu cywilnego, Lex (stan na: 1.05.2014).

${ }^{23}$ T. Wiśniewski, Komentarz do art. $353^{1}$ Kodeksu cywilnego, w: G. Bieniek (red.), Komentarz do Kodeksu cywilnego, ks. III, t. 1, Warszawa 2011, s. 21 i n.

${ }^{24}$ T. Kocowski, Administracyjnoprawne ograniczenia swobody umów, w: B. Gnela (red.), Ustawowe ograniczenia swobody umów. Zagadnienia wybrane, Warszawa 2010, s. 71. 
Należy w tym miejscu postawić pytanie, czy zasada swobody kontraktowej jest wyłączona w odniesieniu do realizacji zadań jednostek samorządu terytorialnego, objętych zakresem ustawy o gospodarce komunalnej, czy jedynie doznaje ograniczeń, tj. czy wyszczególnione powyżej kompetencje (uprawnienia) mieszczące się w zakresie autonomii stron można przypisać jednostkom samorządu terytorialnego. Zagadnienie to od samego początku reaktywowania samorządu terytorialnego nurtowało doktrynę ${ }^{25}$. Bezsprzeczne jest, że działania administracji samorządowej oparte są na zasadzie legalizmu. Determinuje je normatywnie zastrzeżony zakres zadań oraz konstytucyjnie przyznane domniemanie kompetencji samorządu terytorialnego w sprawach niezastrzeżonych dla organów innych władz publicznych. Nie oznacza to jednak, że zasada swobody umów pozostaje w sprzeczności z zasadą legalizmu. Dlatego stwierdzenie, że całość działań gminy jest zdeterminowana prawem i że nie ma w tym zakresie miejsca na ogólnie pojętą swobodę odnośnie do kształtowania przez gminę wraz z jej kontrahentami wiążących je stosunków prawnych o charakterze umownym"26, budzi wątpliwości. Można w tym miejscu postawić pytanie, czy swobodę umowną można rozpatrywać odrębnie od tzw. swobód cząstkowych ${ }^{27}$. W orzecznictwie sądów administracyjnych przyjmuje się, „iż generalnie rzecz biorac, jednostkom samorządu terytorialnego swoboda umów nie przysługuje, jako że w ich przypadku poszczególne cząstkowe elementy tej swobody zostały przez ustawodawcę albo w ogóle wyeliminowane, albo też w bardzo daleko idący sposób ograniczone. To bowiem konkretny przepis prawny, poprzez określenie zadań przekazanych im do realizacji, rozstrzyga o zawarciu danej umowy lub wyłącza tego rodzaju możliwość" 28 .

Jak słusznie zauważa Marek Szydło, nie można negować swobody umów $\mathrm{w}$ odniesieniu do działań jednostek samorządu terytorialnego tylko z tego powodu, że obowiązek realizacji określonego działania wynika z normy prawa administracyjnego ${ }^{29}$. Istnienie choćby jednej swobody czastkowej wynikajacej z autonomii stron umowy (decydowanie o zawarciu umowy, o osobie kontrahenta, o treści umowy oraz jej formie) przesądza o istnieniu tej swobody. Może być ona wyłączona bądź ograniczona tylko na podstawie konkretnego przepisu prawa. Samo założenie nieistnienia (ograniczenia) swobody w przypadku działalności jednostek samorządu terytorialnego, podyktowane obowiąziem realizacji zdań publicznych nie znajduje oparcia w przepisach ustawy o gospodarce komunalnej. Co więcej, przesłanka pełnej zdolności prawnej jednostki samorządu terytorialnego w sferze dominium

25 S. Dudzik, op. cit., s. 181 i n.

26 Tak: ibidem, s. 185.

${ }^{27}$ L. Kieres, Samorzqdowy sektor gospodarczy, w: System prawa administracyjnego, t. 8a: Publiczne prawo gospodarcze, red. J. Grabowski, L. Kieres, A. Walaszek-Pyzioł, Warszawa 2013, s. 127 i n.

${ }^{28}$ Wyrok WSA w Gliwicach z 30 marca 2010 r., IV SA/Gl 33/10, http://orzeczenia.nsa.gov.pl/ doc/3C0182E7ED (dostęp: 20.05.2015). Na temat swobód cząstkowych zob. wyrok WSA w Warszawie z 27 kwietnia 2007 r., VI SA/Wa 2040/06, http://orzeczenia.nsa.gov.pl/doc/C9CFD5C215 [dostęp: 20.05.2015].

${ }_{29}$ M. Szydło, Ustawa o gospodarce..., s. 189. 
jest jej osobowość prawna. Jak słusznie się uznaje, przyjęcie reguł Kodeksu cywilnego do zawierania umów o powierzanie zadań z zakresu gospodarki komunalnej do realizacji jest m.in. następstwem ogólnie obowiązujących reguł prawa cywilnego dotyczącego wykonywania praw podmiotowych przez jednostki samorządu terytorialnego ${ }^{30}$. Dlatego też zasadne jest stwierdzenie, że „W warunkach obowiązywania norm zadaniowych określajacych zadania jednostek samorządu terytorialnego ograniczenia samodzielności w zakresie zaspokajania potrzeb wspólnoty muszą wynikać z wyraźnego przepisu prawa i nie moga opierać się na wykładni rozszerzajaceej czy na domniemaniu"31. Jak zauważył Sąd Najwyższy w wyroku z 27 września 2001 r.: „O tym, czy stronom danego stosunku prawnego przysługuje kompetencja do określonego kształtowania treści tego stosunku, decyduje zawsze zakres swobody kontraktowej przyznanej im w tej mierze przez ustawodawcę" ${ }^{2}$. Zatem przyjąć należy, że swobodę umów mogą ograniczać - po pierwsze - przepisy prawa regulujace zakres zadań przekazanych jednostce samorządu terytorialnego do realizacji, a po drugie - leżący u podstaw każdej z umów obowiązek działania w celu zaspokajania zbiorowych potrzeb wspólnoty samorządowej ${ }^{33}$.

Już w pierwotnej wersji ustawy z 8 marca 1990 r. o samorządzie terytorialnym $^{34}$ art. 9 ust. 1 stanowił, że w celu wykonywania zadań gmina może tworzyć jednostki organizacyjne, w tym przedsiębiorstwa, i zawierać umowy z innymi podmiotami. Wobec braku regulacji dotyczacej zasad i form wykonywania gospodarki komunalnej oraz przepisów określających zasady zawierania umów o powierzenie zadań publicznych formułowano pogląd, że wykonywanie zadań komunalnych odbywa się na podstawie umowy z gmina, a jako przykłady tych umów wskazywano umowy: zlecenie (art. 734-751 k.c.), o dzieło (art. 627-646 k.c.), o roboty budowlane (art. 647-658 k.c.) oraz nienazwane umowy o świadczenie usług (art. 750 k.c.) ${ }^{35}$.

Rozwiązania podobne jak w ustawie o samorządzie gminnym zawiera art. 6 ust. 1 ustawy z 5 czerwca 1998 r. o samorządzie powiatowym ${ }^{36}$ oraz art. 8 ust. 1 ustawy z 5 czerwca 1998 r. o samorządzie województwa ${ }^{37}$. W doktrynie podkreśla się, że przy tworzeniu postanowień umownych, strony umowy (powiat i jego kontrahenci) powinny kierować się naczelną zasadą prawa zobowiązań

30 C. Banasiński, M. Kulesza, Komentarz do art. 3 ustawy o gospodarce komunalnej, Lex (stan na 1.04.2002).

${ }^{31}$ M. Bitner, M. Kulesza, Zasada legalizmu a zdolność kontraktowa jednostek samorzadu terytorialnego, „Samorząd Terytorialny” 19, 2009, nr 6, s. 5 i n.

32 Wyrok z 27 września 2001 r., IV CKN 196/01, Lex, nr 52798.

33 A. Czajka, Dualizm środków ochrony prawnej partnerstw publiczno-prywatnych jednostek samorzadu terytorialnego, w: Samorzad terytorialny w Polsce a sqdowa kontrola administracji, Warszawa 2012, s. 53.

${ }^{34}$ Dz. U. Nr 16, poz. 95. - tekst pierwotny. T.jedn.: obecnie ustawy o samorządzie gminnym Dz. U. 2013, poz. 594 ze zm. (dalej jako: u.s.g.).

${ }^{35}$ A. Szewc, Komentarz do art. 9, w: A. Szewc, G. Jyż, Z. Pławecki, Ustawa o samorzadzie gminnym. Komentarz, Warszawa 2010, s. 135.

36 T.jedn.: Dz. U. 2013, poz. 595 ze zm.

37 T.jedn.: Dz. U. 2013, poz. 596 ze zm. 
- swobody umów, wyrażoną w art. $353^{1}$ k.c. ${ }^{38}$ Swobody tej nie neguje się także w odniesieniu do samorządu województwa ${ }^{39}$.

Ograniczone ramy opracowania nie pozwalają na odniesienie się to zagadnienia szeroko rozumianej współpracy podmiotów publicznych i prywatnych w zakresie wykonywania zadań jednostek samorządu terytorialnego, stąd tylko uwaga, że analiza treści art. 9 ust. 1 u.s.g. nie może pozostawać w oderwaniu od przepisów innych aktów prawnych regulujących sposób realizacji zadania publicznego przez podmiot prywatny lub z jego z udziałem. Dotyczy to w szczególności podstaw prawnych i różnych form współpracy, prowadzących niekoniecznie do zawarcia typowych umów cywilnoprawnych, jak choćby tych, które przewidują możliwość współpracy jednostek samorządu terytorialnego z organizacjami pozarządowymi i opierają się na umowie partnerskiej określonej w art. 28a ust. 1 ustawy z 6 grudnia 2006 r. o zasadach prowadzenia polityki rozwoju ${ }^{40}$ oraz porozumieniu albo umowie o partnerstwie określonych w art. 33 ust. 1 ustawy z 11 lipca 2014 r. o zasadach realizacji programów w zakresie polityki spójności finansowanych w perspektywie finansowej 2014$2020^{41}$. Nowe rozwiązania wskazuja, że określenie „umowa” użyte w art. 9 ust. 1 u.s.g. powinno być rozumiane szeroko i nie może dotyczyć wyłacznie umów cywilnoprawnych.

Wracając do art. 3 ust. 1 u.g.k., podzielić należy pogląd, że odnośnie do „samego faktu zawarcia umowy jednostkom samorządu terytorialnego swoboda przysługuje. Nie wyklucza jej ani art. 3 ust. 1 u.g.k., ani przepisy ustaw, na podstawie których dochodzi do zawarcia umowy. Przepisy prawa nie obligują bowiem jednostek samorządu terytorialnego do zawarcia konkretnej umowy"42. Decyzja o tym, czy zawrzeć umowę, jest podejmowana w sposób samodzielny, autonomiczny ${ }^{43}$. Zauważyć należy, że na samym początku obowiązywania ustawy o gospodarce komunalnej można było spotkać poglądy o konieczności stosowania Prawa zamówień publicznych w każdym przypadku, w którym dochodzi do zawarcia umowy, co słusznie poddawano krytyce ${ }^{44}$.

Przyjąć zatem można, że „kodeks cywilny oraz inne akty prawne nie zawierają przepisów szczególnych, które wyłączałyby stosowanie wobec jednostek samorządu terytorialnego kodeksu cywilnego, a w szczególności art. $353^{1}$ k.c.” ${ }^{45}$. Zasadne jest zatem twierdzenie, że „w sferze użyteczności publicznej jednostkom samorządu terytorialnego przysługuje pewna swoboda

${ }^{38}$ R. Cybulska, Komentarz do art. 8 ustawy o samorzadzie województwa, Lex (stan na: 1.07.2012).

${ }^{39}$ Ibidem

${ }^{40}$ T.jedn.: Dz. U. 2014, poz. 1649.

${ }^{41}$ Dz. U. poz. 1146.

${ }^{42}$ M. Szydło, Ustawa o gospodarce..., s. 191.

${ }^{43}$ C. Banasiński, M. Kulesza, D. Szafrański, Ustawa o gospodarce..., s. 51.

${ }^{44}$ H. Izdebski, Samorzad terytorialny. Podstawy ustroju $i$ działalności, Warszawa 2009, s. 107; A. Matan, Działalność gospodarcza jednostek samorzqdu terytorialnego, w: E. Knosala, M. Kulesza, D. Szafrański (red.), Prawo administracyjne w okresie transformacji ustrojowej, Kraków 1999, s. 245.

${ }^{45} \mathrm{~W}$. Gonet, Zakres swobody zawierania umów przez jednostki samorzadu terytorialnego, Warszawa 2011, s. 62. 
prowadzenia działalności obejmująca swobodę wyboru form ogranizacyjno-prawnych i uprawnienie do podjęcia działalności, co do którego przysługuje domniemanie" 46 .

Jako główny cel wprowadzenia ograniczeń w swobodzie umów zawieranych przez jednostki samorządu terytorialnego podkreśla się ochronę samorządu przed ujemnymi skutkami nadmiernego zadłużenia ${ }^{47}$, negując słabszą pozycję jednostek w obrocie gospodarczym ${ }^{48}$. Wprowadzenie ograniczeń w zakresie gospodarki komunalnej z pewnością znajduje swoje uzasadnienie w ochronie interesu publicznego (samorządowego) ${ }^{49}$. Oznacza to także odpowiedzialność jednostek samorządu terytorialnego za właściwy wybór kontrahenta, a przez to uzyskanie zamierzonego celu w realizacji nałożonych na te jednostki zadań publicznych ${ }^{50}$.

W tym miejscu warto zasygnalizować jeszcze jedną kwestię, która może być rozpatrywana w ramach swobody umów przysługującej jednostkom samorządu terytorialnego, mianowicie, „swobody organizatorskiej”51. Gwarancją tej swobody na gruncie ustawy o samorządzie gminnym jest art. 7 ust. 1 stanowiacy, że zaspokajanie zbiorowych potrzeb wspólnoty należy do zadań własnych gminy, a jej potwierdzeniem - art. 1 ust. 2 u.g.k. definiujacy pojęcie gospodarki komunalnej, które łącznie wraz pozostałymi przepisami ustawy o gospodarce komunalnej składają się na „system prawny gospodarki komunalnej”. System ten tworzy gwarancję organizatorskiej swobody w sferze gospodarki komunalnej ${ }^{52}$, która wyraża się w tym, że w ramach ogólnej normy kompetencyjnej jednostki samorządu terytorialnego dysponują samodzielnością upoważniającą do działania nakierowanego na osiagnięcie określonego celu $^{53}$. W dziedzinie gospodarki komunalnej rządzą bowiem potrzeby mieszkańców jako „odesłanie pozanormatywne zakotwiczone w normie prawnej (art. 7 ust. 1 u.s.g.)" 54 . Nie powinno zatem budzić sprzeciwu spostrzeżenie, że „wszędzie tam, gdzie administracja występuje w roli organizatora życia społecznego [...] determinacja prawna jest inna niż w przypadku działania

${ }^{46}$ R. Hauser, Z. Niewiadomski (red.), Ustawa o samorzqdzie gminnym. Komentarz, Warszawa 2011, s. 138 .

${ }^{47}$ W. Gonet, op. cit., s. 168.

48 Ibidem.

${ }^{49}$ Zob. w szczególności: L. Kieres, Zarzad mieniem publicznym, w: System prawa administracyjnego, t. 8a, s. 722; idem, Samorzqdowy sektor gospodarczy..., s. 121 i n.; A. Borkowski, Dobro wspólne przestanka wspótdziałania podmiotów publicznych i prywatnych w obszarze gospodarki komunalnej, „Przegląd Prawa i Administracji” 98, 2014, s. 16 i n.; A. Borkowski, Interes publiczny jako determinant działań władzy publicznej i klauzula generalna $w$ publicznym prawie gospodarczym, w: L. Kieres (red.), Nowe problemy badawcze w teorii publicznego prawa gospodarczego (z uwzględnieniem samorzadu terytorialnego), Wrocław 2010, s. 9 i n; A. Borkowski, Interes publiczny a partnerstwo publiczno-prywatne, w: J. Blicharz (red.), Prawne aspekty prywatyzacji, Wrocław 2012, s. 443 i n.

50 A. Borkowski, Interes publiczny jako determinant..., s. 17.

51 T. Kuta, Aspekty prawne działań administracji publicznej w organizowaniu usług, Wrocław 1969, s. 69.

${ }_{52}$ M. Kulesza, op. cit., s. 19.

${ }^{53}$ K. Kokocińska, op. cit., s. 82.

${ }^{54}$ M. Kulesza, op. cit., s. 20. 
praw i wolności indywidualnej jednostki ${ }^{55}$. Na zróżnicowanie determinacji prawnej działań administracji zwracał już uwagę Tadeusz Kuta, stwierdzając, że w obrębie administracji władczej zasada legalizmu powinna być ściśle przestrzegana, natomiast w obrębie administracji wykonującej funkcje organizacyjne ustawodawca przydziela administracji pewną dozę swobody poruszania się ${ }^{56}$. Potrzebę istnienia swobody w działalności jednostek samorządu terytorialnego dostrzega także Irena Lipowicz, uznając, że administracja nie może być bezwolnym wykonawcą prawa i że ma ona dość swobody, aby nadać określonej normie zróżnicowaną treść uzależnioną od potrzeb społecznych i sytuacji politycznej ${ }^{57}$. Stąd w działaniach organizacyjnych administracji kształtującej zauważa się, że związanie ustawowe jest „z zasady luźne”58. Co ważne, także sądy administracyjne dostrzegają wagę swobody w działalności jednostki samorządu terytorialnego, stwierdzając, że „Nie można odmówić gminie, jako jednemu z podmiotów, którym Rzeczpospolita Polska gwarantuje swobodę działalności gospodarczej (art. 6 Konstytucji), prawa do takiego gospodarowania mieniem komunalnym, które przyniesie najkorzystniejsze efekty"59.

Właściwe rozumienie potrzeb społecznych przez ustawodawcę powinno zatem przejawiać się w zagwarantowaniu ich realizacji w ramach szerokiego wachlarza prawnych form działania, a także czynności organizatorskich, których zastosowanie nie powinno mieć charakteru obligatoryjnego; powinno dawać jednostkom samorządu terytorialnego możliwość wyboru czynności zmierzających do oczekiwanego rezultatu.

\section{OGRANICZENIA USTAWOWE SWOBODY UMÓW}

W art. 3 ust. 1 u.g.k. mowa jest o umownym „powierzaniu” wykonywania zadań z zakresu gospodarki komunalnej, które powinno być rozumiane „możliwie szeroko, jako obejmujące zarówno powierzenie zadań sensu stricto (tj. ich pierwotne przekazanie), jak i wsparcie wykonywania pewnych zadań, wraz z udzieleniem na ten cel stosownej dotacji”60.

Z uwagi na ramy opracowania autorka zwróci uwagę tylko na pewne kwestie dotyczące wyboru strony umowy (partnera), formy umowy oraz trybu kontroli czynności podejmowanych w postępowaniu prowadzącym do wyboru strony umowy, a także kontroli samej umowy.

${ }^{55}$ K. Kokocińska, op. cit., s. 82.

${ }^{56}$ T. Kuta, Funkcje wspótczesnej administracji i sposoby jej realizacji, Wrocław 1992, s. 79.

${ }^{57}$ I. Lipowicz, Istota administracji, w: Z. Niewiadomski (red.), Prawo administracyjne, Warszawa 2009 , s. 22.

${ }_{58}$ M. Kulesza, Administracyjnoprawne uwarunkowania polityki przestrzennej, Warszawa 1987, s. 203.

${ }^{59}$ Wyrok NSA - Ośrodek Zamiejscowy w Gdańsku z 4 kwietnia 1991 r., SA/Gd 23/91, www. orzeczenia.nsa.gov.pl.

${ }^{60}$ M. Szydło, Umowne powierzanie wykonywania zadań z zakresu gospodarki komunalnej przez jednostki samorzadu terytorialnego, „Finanse Komunalne” 2007, nr 4, s. 5. 


\section{Wybór partnera}

Powierzenie wykonania zadań jednostki samorządu terytorialnego co do zasady obwarowane jest koniecznością wyboru strony umowy (partnera, kontrahenta, oferenta) w sposób gwarantujący zachowanie uczciwej i wolnej konkurencji oraz przestrzeganie zasad równego traktowania, przejrzystości i proporcjonalności. Zapewnieniem realizacji tych zasad jest wprowadzenie wymogu publikowania ogłoszeń o wyborze oferenta oraz konkursowych trybów wyboru. Tryb konkursowy przewidziany jest we wszystkich ustawach stanowiących podstawę zawarcia umowy o powierzenia zadania z zakresu gospodarki komunalnej, z wyjątkiem ustawy o finansach publicznych W przypadku tej ustawy zlecenie zadania i udzielenie dotacji może bowiem nastapić zgodnie z przepisami ustawy o działalności pożytku publicznego, jeżeli mieści się w katalogu zadań w niej wskazanych, a jeżeli dotyczy ono innych zadań - na podstawie umowy jednostki samorządu terytorialnego z podmiotem. W drugiej sytuacji tryb postępowania o udzielenie dotacji, sposób jej rozliczania oraz sposób kontroli wykonywania zleconego zadania określa w drodze uchwały organ stanowiący jednostki samorządu terytorialnego, mając na uwadze zapewnienie jawności postępowania o udzielenie dotacji i jej rozliczenia ${ }^{61}$.

Stosunkowo szeroki zakres swobody kontraktowej przewiduje ustawa o działalności pożytku publicznego, choć inaczej niż w przypadku ustawy o finansach publicznych reguluje tryb wyboru oferenta. Wspieranie oraz powierzanie zadań publicznych wymaga przeprowadzenia otwartego konkursu ofert, chyba że przepisy odrębne przewiduja inny tryb zlecania. W sytuacji gdy wspieranie oraz powierzanie zadań publicznych jest finansowane z niepodlegających zwrotowi środków pochodzących ze źródeł zagranicznych, wybór może natomiast nastapić na zasadach i w trybie ustawy o partnerstwie publiczno-prywatnym albo na podstawie umów międzynarodowych. W szczególnych sytuacjach ustawodawca dopuszcza także zlecenie zadań publicznych z pominięciem otwartego konkursu ofert (art. 11a, art. 11b, art. 11c, art. 19a u.d.p.p.w.). Przepis art. 13 u.d.p.p.w. stanowi, że organ administracji publicznej zamierzajacy zlecić realizację zadania publicznego ogłasza otwarty konkurs ofert. Ustawa określa elementy tego ogłoszenia (art. 13 ust. 1 u.d.p.p.w.), niezbędne elementy oferty (art. 14 ust. 1 u.d.p.p.w.) oraz kryteria oceny ofert (art. 15 ust. 1 u.d.p.p.w.).

Także Prawo zamówień publicznych szczegółowo reguluje zasady dokonywania ogłoszeń, przygotowanie postępowania w sprawie zamówienia publicznego oraz tryb wyboru oferty, ustanawiajac w przepisach szereg ograniczeń w zakresie zawierania umów. Z uwagi na liczne i ugruntowane poglądy doktryny $^{62}$ oraz praktyki wskazujące na te ograniczenia warto podkreślić tylko

${ }^{61}$ M. Kisała, Stosowanie formy umowy cywilnoprawnej przez jednostki samorzqdu terytorialnego w powierzaniu wykonywania zadań publicznych, w: A. Doliwa et al. (red.), Kryzys prawa administracyjnego? Wypieranie prawa administracyjnego przez prawo cywilne, Warszawa 2012 , s. 242 .

${ }^{62}$ W szczególności: A. Panasiuk, Umowy w zamówieniach publicznych, Poznań 2001; M. Guziński (red.), Zamówienia publiczne jako przedmiot regulacji prawnej, Wrocław 2012; idem, Procedura powierzania realizacji zadania komunalnego w trybie ustawy Prawo zamówień publicz- 
to, że jednym z najistotniejszych ograniczeń jest z pewnością brak dowolności wyboru kontrahentów, co wynika z ustanowienia zamkniętego katalogu trybów postępowania. Zgodnie z art. 7 ust. 1 p.z.p. zamówienia można udzielić wyłacznie wykonawcy wybranemu zgodnie z przepisami ustawy.

Wybór partnera na gruncie ustawy o partnerstwie publiczno-prywatnym pozostawiony jest $\mathrm{w}$ gestii podmiotu publicznego, co podkreśla otwarty charakter partnerstwa ${ }^{63}$. W zależności od zasad wynagrodzenia partnera prywatnego i sposobu finansowania przedsięwzięcia stosuje się przepisy ustawy o koncesji na roboty budowlane albo Prawa zamówień publicznych. Ustawa przewiduje także trzeci tryb wyboru partnera w sposób gwarantujący zachowanie uczciwej i wolnej konkurencji oraz przestrzeganie zasad równego traktowania, przejrzystości i proporcjonalności, przy odpowiednim uwzględnieniu przepisów ustawy o partnerstwie publiczno-prywatnym, a w przypadku wniesienia przez podmiot publiczny wkładu własnego będącego nieruchomościa także przepisów ustawy z 21 sierpnia 1997 r. o gospodarce nieruchomościami (np. w zakresie realizacji zadań w sektorze telekomunikacyjnym) ${ }^{64}$.

O sformalizowanym postępowaniu dotyczącym wyboru partnera można także mówić w przypadku ustawy o koncesji na roboty budowlane Postępowanie to wszczynane jest w drodze publicznego ogłoszenia o koncesji (art. 10-12 u.k.r.b.u.), którego wymóg wynika także z dyrektywy Parlamentu Europejskiego i Rady 2014/23/UE z 26 lutego 2014 r. w sprawie udzielania koncesji ${ }^{65}$. Wyłonienie koncesjonariusza wymaga negocjacji (art. 14 u.k.r.b.u.), a następnie w wyboru najkorzystniejszej oferty (art. 17 u.k.r.b.u). Kryteria oceny ofert pozostawiono koncesjodawcy ${ }^{66}$. Nie oznacza to jednak dowolności. Specyfika postępowania w sprawie zawarcia umowy o koncesję na roboty budowlane lub usługi sprowadza się do tego, że musi być ono przygotowane i przeprowadzone w sposób zapewniajacy równe i niedyskryminacyjne traktowanie zainteresowanych podmiotów. Organ zobligowany jest działać w sposób przejrzysty oraz $\mathrm{z}$ zachowaniem zasad uczciwej konkurencji ${ }^{67}$.

Wybór operatora publicznego transportu zbiorowego zgodnie z przepisami ustawy o publicznym transporcie może być dokonywany w trybie Prawa zamówień publicznych, ustawy o koncesji na roboty budowlane oraz w trybie art. 22 ust. 1 u.p.t.z. (w drodze bezpośredniego zawarcia umowy). Przy czym przeprowadzenie postępowania wymaga ogłoszenia. W myśl art. 21 ust. 1 u.p.z.t. w specyfikacji istotnych warunków zamówienia można uwzględnić w szczególności normy jakości i powszechną dostępność świadczonych usług. Szczegółową regulację tych kwestii pozostawiono uznaniu operatora.

Na marginesie zauważyć można, że wybór partnera bywa powiąany z innymi działaniami jednostki samorządu terytorialnego, które przybierają bądź

\footnotetext{
nych, w: B. Popowska (red.), Swoistość procedur publicznego prawa gospodarczego, Poznań 2013, s. 206 i n.

${ }^{63}$ A. Trela, Kwalifikacja prawna umowy o partnerstwie publiczno-prywatnym $w$ świetle orzecznictwa sqdów administracyjnych, „Przegląd Prawa i Administracji” 98, 2014, s. 95 in.

${ }^{64}$ Ibidem, s. 97.

${ }_{65}$ Dz. Urz. UE L.94/1.

${ }^{66}$ Druk sejmowy 834.

${ }^{67}$ Wyrok WSA w Łodzi z 23 lutego 2012 r., III SA/Łd 55/12, www.orzeczenia.nsa.gov.pl.
} 
formę uchwały programowej (roczny program współpracy z organizacjami pozarządowymi), bądź aktu prawa miejscowego, którym jest plan zrównoważonego rozwoju publicznego transportu zbiorowego.

\section{Umowa}

Elementy umowy o dotację lub zlecenie zadania w sposób bardzo ogólny określa ustawa o finansach publicznych (art. 221 ust. 3). Szczegółowo essentialia negotii umowy wymieniaja przepisy ustawy o koncesji na roboty budowlane (22 ust. 1 pkt 1-14) oraz ustawy o publicznym transporcie (art. 25 ust. 3 pkt 1-23), pozostawiając jednak stronom możliwość ich doprecyzowania. Także umowa, której wzór został ustalony na podstawie delegacji ustawowej zawartej w art. 19 ust. 1 u.d.p.p.w., w rozporządzeniu Ministra Pracy i Polityki Społecznej z 15 grudnia 2010 r. w sprawie wzoru oferty i ramowego wzoru umowy dotyczacych realizacji zadania publicznego oraz wzoru sprawozdania z wykonania tego zadania ${ }^{68}$, nie ma charakteru obligatoryjnego, a jedynie ramowy. Z kolei ustawa o partnerstwie publiczno-prywatnym nie wskazuje wymogów kształtujących treść umowy, a jedynie określa, że umowa o tego typu partnerstwie to zobowiązanie podmiotu prywatnego do realizacji przedsięwzięcia za wynagrodzeniem oraz poniesienia w całości albo w części wydatków na jego realizację lub poniesienia ich przez osobę trzecią. Podmiot publiczny zobowiązuje się w tej umowie do współdziałania w osiagnięciu celu przedsięwzięcia, w szczególności przez wniesienie wkładu własnego. Takie rozwiązanie daje możliwość kształtowania odmiennych treści umowy o partnerstwie publiczno-prywatnym ${ }^{69}$.

Co do formy umowy to ustawa o finansach publicznych nie reguluje tej kwestii. Zgodnie natomiast z ustawą o działalności pożytku publicznego zawarcie umowy wymaga zastosowania formy pisemnej pod rygorem nieważności. W takiej samej formie zwierana jest umowa koncesji (art. 21 ust. 5 u.k.r.b.u.) oraz umowa o zamówienie publiczne (art. 139 ust. 2 p.z.p.). W przypadku umowy o partnerstwie publiczno-prywatnym i umowy o świadczenie usług w zakresie transportu publicznego do formy umowy znajdują zastosowanie także przepisy Prawa zamówień publicznych albo ustawy o koncesji na roboty budowlaneczyli forma pisemna pod rygorem nieważności.

Umowy o powierzenie zadania publicznego zawierane na podstawie ustawy o finansach publicznych oraz ustawy o działalności pożytku publicznego są umowami cywilnoprawnymi ${ }^{70}$. Charakter cywilnoprawny maja także umowy zawierane na gruncie Prawa zamówień publicznych ${ }^{71}$. Przemawia za

68 Dz. U. 2011, Nr 6, poz. 25.

69 A. Trela, op. cit., s. 100 i n.

${ }^{70} \mathrm{Z}$ załącznika nr 2 do rozporządzenia wynika, że w zakresie nieuregulowanym umową stosuje się przepisy k.c.

71 B. Popowska, Partnerstwo publiczno-prywatne w świetle koncepcji „ciagu działań prawnych” $i$ jej wpływ na ocene umowy o PPP, w: L. Kiers (red.), Środki prawne publicznego prawa gospodarczego, Wrocław 2007 s. 156; eadem, Publiczne prawo gospodarcze w płaszczyźnie proceduralnej, w: L. Kieres (red.), Nowe problemy badawcze w teorii publicznego prawa gospodarczego (z uwzględnieniem samorzadu terytorialnego), Wrocław 2010, s. 231; K. Horubski, Publiczno- 
tym art. 14 p.z.p., który stanowi, że do czynności podejmowanych przez zamawiającego i wykonawców w postępowaniu o udzielenie zamówienia stosuje się przepisy Kodeksu cywilnego, jeżeli przepisy ustawy nie stanowią inaczej. Do umów, podobnie jak i do czynności podejmowanych przez zamawiającego i wykonawców, stosuje się także przepisy k.c., zgodnie z art. 139 p.z.p.

Znamienne jest, że regulacje prawne wprowadzajace nowe formy realizacji zadań publicznych przez jednostki samorządu terytorialnego nie określają w sposób jednoznaczny ich charakteru prawnego ${ }^{72}$. Dotyczy to m.in. umowy o partnerstwie publiczno-prywatnym oraz umowy o koncesji. Choć w odniesieniu do tej pierwsze dominują poglądy o jej cywilnoprawnym charakterze $^{73}$, spotkać można się także z koncepcjami uznawania jej za umowę publicznoprawną ${ }^{74}$, a także umowę o charakterze mieszanym ${ }^{75}$. Podobnie nie ma też jednolitego poglądu co do charakteru umowy o koncesji ${ }^{76}$.

Odnośnie do obowiązywania swobody umów przy zawieraniu umów publicznoprawnych uważa się, że jedną z cech umowy publicznoprawnej jest względna swoboda zawierania umowy, ograniczona jedynie konkurencyjnoeliminacyjnymi procedurami wyboru partnera ${ }^{77}$. Umowa taka dochodzi do skutku w drodze negocjacji między administracją publiczną a podmiotem zewnętrznym, który staje wobec administracji na równorzędnej pozycji ${ }^{78}$. Można spotkać także i taki pogląd, że w przypadku zawierania umów publicznoprawnych zasada swobody kontraktowej nie obowiazuje ${ }^{79}$, co jest konsekwencją rozdzielenia w prawie administracyjnym wolności i kompetencji ${ }^{80}$. Zauważa się jednak, że osiagnięcie wspólnego kompromisu

i prywatnoprawne elementy zamówień publicznych, „Państwo i Prawo” 64, 2009, z. 7, s. 83-84; R. Stober, op. cit., s. 249; E. Schmidt-Assmann wskazuje, że w doktrynie prawa niemieckiego można znaleźć poglądy o konieczności oceny zamówień publicznych pod kątem teorii dwóch stopni, pozwalającej oddzielić rozstrzygnięcie w przedmiocie wyboru oferenta od zawarcia umowy, idem, Ogólne prawo administracyjne jako idea porzadku. Założenia i zadania tworzenia systemu prawnoadministracyjnego, Warszawa 2011, s. 368.

${ }^{72}$ Zob. T. Rabska, Kontrakt wojewódzki-forma działania administracji publicznej w strukturach zdecentralizowanych, w: I. Skrzydło-Niżnik et al. (red.), Instytucje współczesnego prawa administracyjnego. Księga jubileuszowa Profesora zw. dra hab. Józefa Filipka, Kraków 2001, s. 601 i n.; zob. też B. Popowska, Partnerstwo publiczno-prywatne..., s. 156.

${ }^{73}$ D. Kijowski, Problematyka regulacji prawnej stosowania form alternatywnych wobec aktu administracyjnego, w: J. Zimmermann (red.), Koncepcja sytemu prawa administracyjnego. Zjazd Katedr Prawa Administracyjnego i Postepowania administracyjnego, Zakopane 24-27 września 2006 r., Warszawa 2007, s. 434; E. i E. Ura, Prawo administracyjne, Warszawa 2006, s. 114.; A. Zimmermann, Prawo administracyjne, Warszawa 2006, s. 349.

${ }^{74}$ D. Dolnicki, R. Cybulska, Nowe dwustronne formy działania administracji publicznej-zagadnienia wybrane, w: J. Zimmermann (red.), op. cit., s. 472.

75 M. Kania, Umowa o partnerstwie publiczno-prywatnym. Studium administracyjnoprawne, Katowice 2013, s. 366; A. Wiktorowska, Kierunki zmian w teorii prawnych form działania administracji, w: J. Zimmermann (red.), op. cit., s. 382.

${ }^{76}$ L. Lipiec-Warzecha, Komentarz do art. 22 ustawy o koncesji na roboty budowlane lub ustugi, Lex (stan na: 26.07.2012); A. M. Waligórski, Model prawny umowy koncesji na roboty budowlane lub ustugi, w: S. Wrzosek et al. (red.), Wspótzależność dyscyplin badawczych w sferze administracji publicznej, Warszawa 2010, s. 301.

77 A. Panasiuk, op. cit., s. 30.

78 J. Zimmermann, op. cit., s. 344.

${ }^{79}$ K. Strzyczkowski, Prawo gospodarcze publiczne, Warszawa 2009, s. 208.

${ }^{80}$ E. Schmidt-Assmann, op. cit., s. 436. 
interesów pozwala jednak na dokonywanie „subtelnych uzgodnień, które obowiązuja jako efekt pozytywny umownego kształtowania" ${ }^{81}$. W odniesieniu jednak do umów publicznoprawnych niezbędna jest regulacja ustawowa znajdująca wyraz w „zasadzie ustawowo kierowanego kształtowania umów"82.

\section{Kontrola}

Zasady kontroli czynności podejmowanych w postępowaniu o udzielenie zamówienia określa art. 180 i n. p.z.p., stanowiąc, że od czynności zamawiającego podjętej niezgodnie z przepisami ustawy podjętej w postępowaniu o udzielenie zamówienia lub zaniechania czynności, do której zamawiajacy jest zobowiązany na podstawie ustawy, służy odwołanie do Krajowej Izby Odwoławczej (KIO), wnoszone do Prezesa. Natomiast na orzeczenie KIO stronom oraz uczestnikom postępowania odwoławczego przysługuje skarga do sądu powszechnego.

W przypadku czynności podejmowanych na podstawie ustawy o działalności pożytku publicznego sądy administracyjne uznają że skoro procedura konkursowa nie jest oparta na przepisach ustawy z 14 czerwca 1960 r. - Kodeks postępowania administracyjnego ${ }^{83}$, a ogłoszenie wyników postępowania konkursowego nie ma cech decyzji administracyjnej, a także w ramach tej procedury organ, udzielajac dotacji, nie orzeka o uprawnieniach i obowiązkach wnioskodawcy, to tym samym kontrola sądowa działań podejmowanych w postępowaniu o zlecenie zadania publicznego jest wyłączona ${ }^{84}$. Kontrolą tą są natomiast objęte spory dotyczace zwrotu dotacji, albowiem w zakresie nieuregulowanym ustawą o działalności pożytku publicznego do nadzoru i kontroli wydatkowania środków publicznych stosuje się odpowiednio przepisy ustawy o finansach publicznych ${ }^{85}$.

Stosownie natomiast do treści art. 27 ust. 1 u.k.r.b.u., uczestnicy moga wnieść skargę do wojewódzkiego sądu administracyjnego. Przedmiotem skargi może być każda kolejna czynność podejmowana przez organ w toku postępowania, począwszy od ogłoszenia i określonych w nim warunków, na wyborze najkorzystniejszej oferty skończywszy ${ }^{86}$. Podstawą skargi na czynności koncesjodawcy może być naruszenie tylko przepisów ustawy o koncesji na roboty budowlane ${ }^{87}$.

Tryb kontroli czynności podejmowanych w celu bezpośredniego zawarcia umowy oświadczenie usług w zakresie publicznego transportu określa art. 59 u.p.t.z., stanowiąc, że w przypadku ogłoszenia zamiaru bezpośredniego zawarcia umowy, o którym mowa w art. 23 ust. 1, podmiotowi, który jest lub był zainteresowany zawarciem danej umowy i któremu grozi powstanie szkody

\footnotetext{
81 Ibidem, s. 439 .

82 Ibidem, s. 438

83 T.jedn.: Dz. U. 2013, poz. 267 ze zm.

${ }^{84}$ Wyrok NSA z 30 listopada 2011 r., II GSK 2022/11, Lex, nr 1151678.

85 Wyrok WSA w Opolu z 15 września 2010 r., I SA/Op 454/10, Lex, nr 749741.

86 Wyrok WSA w Łodzi z 23 lutego 2012 r., III SA/Łd 55/12, www.orzeczenia.nsa.gov.pl.

87 Wyrok NSA z 28 stycznia 2015 r., II GSK 1589/14, www.orzeczenia.nsa.gov.pl.
} 
w wyniku zarzucanego naruszenia przepisów prawa Unii Europejskiej lub ustawy, przysługuje prawo wniesienia skargi do sądu administracyjnego ${ }^{88}$. Sądy administracyjne stoją na stanowisku, że postanowienia ustawy o publicznym transporcie wyraźnie wskazuja, że nie wszystkie działania organizatora podlegają kontroli sądowej. W orzecznictwie sądowym jako czynności organizatora, na jakie dopuszczalne jest wniesienie skargi na podstawie art. 59 ust. 1 u.p.t.z., kwalifikowane były takie czynności, jak: dokonanie ogłoszenia o zamiarze przeprowadzenia postępowania ${ }^{89}$ oraz uchwała jednostki samorzadu terytorialnego w sprawie zawarcia umowy o świadczenie usług w zakresie publicznego transportu zbiorowego.

\section{PODSUMOWANIE}

Niewatpliwie proces tworzenia sytemu gospodarki komunalnej nadal się kształtuje, dostosowujac model gospodarki komunalnej do potrzeb gospodarki rynkowej, uwarunkowanej licznymi wpływami prawa unijnego. Dotyczy to także wprowadzania nowych form realizacji zadań z zakresu gospodarki komunalnej dających możliwość skutecznego i efektywnego reagowania samorządu na potrzeby wspólnoty w zakresie gospodarki komunalnej. Aktywność jednostek samorządu terytorialnego, a szczególnie gminy, w sferze gospodarki komunalnej wymaga bowiem stosowania różnych i często wzajemnie powiązanych działań. Podstawę prawną tych działań wyznacza ustawodawca, kształtując formy prawne działania administracji samorządowej z uwzględnieniem zagwarantowanej prawnie samodzielności tych jednostek. Potrzeba osiagania celów adekwatnych do potrzeb wspólnoty sprawia, że postanowienia ustawowe pozwalają administracji samorządowej realizować gospodarkę komunalną w drodze umów. Przyznana przez ustawodawcę w tym zakresie swoboda może być rozpatrywana jako przejaw swobody kontraktowej, ograniczonej przez system prawny. Przepisy prawa publicznego pozostawiają w ograniczonym stopniu jednostkom samorządu terytorialnego możliwość wyboru trybu zawarcia umowy. Wybór określonego typu umowy o powierzenie wykonania zadania publicznego należy także do kompetencji jednostek samorządu terytorialnego.

Swoboda kontraktowa jednostek samorządu terytorialnego na gruncie gospodarki komunalnej powinna być rozpatrywana przez pryzmat elementów składających się na swobodę umów (tzw. swobód cząstkowych). Swoboda ta doznaje w mniejszym lub większym zakresie ograniczeń w zakresie kształtowania treści umów o powierzeniu zadania z zakresu gospodarki komunalnej. Różne typy umów zawierane są w ramach różnych trybów wyboru kontrahenta, to jednak i w tym zakresie swoboda ta przysługuje i jest stosunkowo szeroka. Pamiętać jednak należy, że przepisy prawa cywilnego mają jedynie charakter subsydiarny wobec przepisów prawa publicznego, wprowadzających szereg odmienności i ograniczeń w zakresie swobody umów.

\footnotetext{
88 Wyrok NSA z 24 czerwca 2014 r., II GSK 597/13, www.orzeczenia.nsa.gov.pl.

${ }^{89}$ Wyrok WSA w Gliwicach z 21 grudnia 2012 r., II SA/Gl 1267/12, www.orzeczenia.nsa.gov.pl.
} 
Jeśli chodzi o kontrolę swobody przyznanej jednostkom samorządu terytorialnego, to jest ona zróżnicowana. W przypadku umów o zamówienie publiczne czynności zmierzające do zawarcia umowy, a także sama umowa podlegaja kontroli ze strony sądów powszechnych. Inaczej jest w przypadku czynności podejmowanych w celu zawarcia umowy o koncesję i umowy o oświadczenie usług w zakresie publicznego transportu, które podlegają kontroli sądów administracyjnych, a sama umowa - kontroli sąów powszechnych. Postulować należy wprowadzenie jednolitego system kontroli umów i czynności prowadzących do ich zawarcia.

dr Anna Trela

Uniwersytet im. Adama Mickiewicza w Poznaniu

atrela@amu.edu.pl

\section{HANDING OVER TASKS OF COMMUNAL ECONOMY VERSUS A FREEDOM TO CONTRACT}

\section{Sum mary}

The paper is an analysis of Article 3 clause 1 of the Communal Economy Act on the scope of freedom to contract granted to units of local self-government. In the first part, the main issues characterising the freedom to contract are presented and are then analysed in the context of the legal grounds upon which local self-government units function and exist as legal entities. As is shown based on this analysis, communal economy law lacks a regulation by which it would exclude the freedom to contract, while that freedom could be, in principle, limited by provisions regulating the scope of tasks vested in a self-government unit. What is more, the duty underlying each such contract obliges local self-government units to satisfy the collective needs of the community. What is known as Organisational Freedom is also analysed. The second part addresses the limitations of the freedom to contract imposed by law on local self-government units, including the choice of deciding upon the way in which a public task is to be realised, the choice of a business partner or a tenderer, or the power to decide upon the content of a contract to be entered into. Regarding the latter, it is concluded that the provisions of civil law are only of a subsidiary character with regard to public law which introduces many varieties and limitations of the freedom of contract. 